\title{
Fast analysis of low molecular mass compounds present in snake venom: identification of ten new pyroglutamate-containing peptides
}

\author{
Luciana Serrão Wermelinger ${ }^{1,2}$, Denis L. S. Dutra ${ }^{1,2}$, Ana L. Oliveira-Carvalho ${ }^{1,2}$, \\ Márcia Regina Soares ${ }^{3}$, Carlos Bloch $\mathrm{Jr}^{3,4}$ and Russolina B. Zingali ${ }^{1,2 *}$ \\ ${ }^{1}$ Laboratório de Proteoma e Microsseqüenciamento de Proteínas e Petídeos, Instituto de Bioquímica Médica, Centro de Ciências da Saúde, \\ Universidade Federal do Rio de Janeiro, Rio de Janeiro, Brazil \\ ${ }^{2}$ Rede Proteômica do Rio de Janeiro, Rio de Janeiro, Brazil \\ ${ }^{3}$ Laboratório de Espectrometria de Massa, Laboratório Nacional de Luz Síncrotron, Campinas, São Paulo, Brazil \\ ${ }^{4}$ Laboratório de Espectrometria de Massa, Embrapa Recursos Genéticos e Biotecnologia, Brasília-DF, Brazil \\ Received 21 February 2005; Revised 12 April 2005; Accepted 13 April 2005
}

\begin{abstract}
Characterization of the peptide content in snake venoms can be an important tool for the investigation of new pharmacological lead compounds. For this purpose, single-step analysis of crude venoms has recently been demonstrated using mass spectrometry (MS) techniques. Reproducible profiles of ions in MS and MS/MS spectra may also be used to compare venoms from different species. In this work matrix-assisted laser desorption/ionization time-of-flight mass spectrometry (MALDI-TOFMS) was used to obtain mass patterns of the major peptides $(<8 \mathrm{kDa})$ found in pooled venoms from the genera Bothrops and Crotalus. Venoms from five different Bothrops species (B. jararaca, B. insularis, B. alternatus, B. jararacussu, and B. neuwiedi) and three Crotalus species (C. viridis, $C$. adamanteus and $C$. durissus terrificus) were analyzed. In agreement with other reports, venoms from Bothrops species contained a variety of peptides in the range $\mathrm{m} / z \mathbf{~ 1 0 0 0 -}$ 1500 , and in some samples larger components $(\mathrm{m} / \mathrm{z} 7000-8000)$ were detected. In the Crotalus species venoms were rich in peptides ranging from $\mathrm{m} / z$ 1000-1500 and 4000-5500. MS/MS experiments on the low molecular mass peptides $(\mathrm{m} / z$ 1000-1500) confirmed the presence of ten new bradykinin-potentiating peptides among venoms from genera Bothrops and Crotalus. In order to determine whether additional peptides could be identified after partial purification, $B$. jararaca venom was subjected to size-exclusion chromatography on Sephacryl S-200, and two distinct low molecular mass pools were analyzed further by MALDI-TOFMS. No additional peptides were detected from the pool with masses below $2000 \mathrm{Da}$ but a substantial improvement with better resolution was observed for the pool with masses above $7000 \mathrm{Da}$, indicating that complex samples such as crude snake venoms can be analyzed for low molecular mass peptides using a single-step procedure. Copyright (C) 2005 John Wiley \& Sons, Ltd.
\end{abstract}

Snake venoms contain a large number of biologically active substances. ${ }^{1}$ However, they also contain a number of small protein and peptide components whose biological functions are still undetermined. Several peptides and small proteins from snake venoms have been purified in recent years, including the bradykinin-potentiating peptides (BPPs), disintegrins and myotoxins. BPPs are proline-rich peptides composed of 5 to 13 amino acid residues with a pyroglutamic

${ }^{*}$ Correspondence to: R. B. Zingali, Instituto de Bioquímica Médica, UFRJ, Av. Brigadeiro Trompovski s/n, 21941-590, Rio de Janeiro, RJ, Brazil.

E-mail: lzingali@bioqmed.ufrj.br

Contract/grant sponsor: Conselho Nacional de Desenvolvimento Científico (CNPq), Fundação de Amparo à Pesquisa do Estado do Rio de Janeiro (FAPERJ), Coordenação de Aperfeiçoamento de Pessoal de Nível Superior (CAPES), Laboratório Nacional de Luz Síncrotron (LNLS) and Fundação de Amparo à Pesquisa do Estado de São Paulo (FAPESP) (Brazil). acid residue at the $\mathrm{N}$-terminus. These molecules inhibit the angiotensin-converting enzyme, thus potentiating the activity of bradykinin and causing hypotensive effects. ${ }^{2,3}$ Disintegrins are low molecular mass $(6-8 \mathrm{kDa})$ cysteine-rich peptides cointaining an Arg-Gly-Asp (RGD) motif, isolated from the venoms of various Viperidae. These molecules recognize integrin receptors on cell surfaces; they are potent inhibitors of platelet aggregation and act as modulators of neutrophil function. ${ }^{4-6}$ Myotoxins such as crotamine are basic polypeptides with molecular mass of 4.5-5.0 kDa that cause muscle necrosis after snake envenomation. These toxins can induce membrane depolarization-dependent muscle contractions by increasing the $\mathrm{Na}^{+}$permeability of skeletal muscle membranes. ${ }^{7,8}$

The heterogeneity of venoms may account for differences in the clinical symptoms observed in snake-bite accidents. Extensive tissue necrosis, coagulopathy and arterial 
hypotension are a frequent finding in Bothrops envenomation. On the other hand, accidents involving Crotalus species are associated with neurotoxic symptoms, severe muscle necrosis, paralysis, and a moderate effect on blood coagulation. ${ }^{1,2,4,9,10}$

Characterization of the peptide content of snake venoms has a number of potential benefits for basic research, clinical diagnosis, development of new therapeutic agents and production of antiserum. In order to analyze in detail the peptides and small proteins of crude samples, techniques such as chromatography and electrophoresis have been employed. ${ }^{2,11}$ More recently, it has been demonstrated that mass spectrometry customized for proteomics needs is a powerful tool for analysis of complex mixtures of proteins and peptides, in particular crude venoms. Thus, matrixassisted laser desorption/ionization time-of-flight mass spectrometry (MALDI-TOFMS) has shown intraspecific geographic variations in Trimeresurus stejnegeri venoms. ${ }^{12}$ Tandem mass spectrometry (MS/MS) has become the fastest technique for determining the primary structures of a diversity of peptides and their post-translational modifications. ${ }^{13,14}$

The aim of the present work was to investigate directly by MS the peptide content of crude snake venoms, prior to any purification step, in order to avoid loss of minor components or interference of any kind. MALDI-TOFMS and de novo sequencing analysis yielded ten new BPP sequences among venoms from the two genera investigated. Taken together, the results indicate the usefulness of this single-step approach for low molecular mass compounds in complex samples such as raw venoms and secretions.

\section{EXPERIMENTAL}

\section{Venom samples}

Pooled venoms from five Bothrops species (B. jararaca, B. insularis, B. jararacussu, B. alternatus, and B. neuwiedi) were kindly provided by Instituto Butantan (São Paulo, SP, Brazil). Crotalus viridis and $C$. adamanteus were from Latoxan (Valence, France) and C. durissus terrificus was from CEVAP (Botucatu, São Paulo, Brazil). Venom samples ( $3 \mathrm{mg} / \mathrm{mL}$ dry weight) were reconstituted in $20 \mathrm{mM}$ Tris, $150 \mathrm{mM} \mathrm{NaCl}, \mathrm{pH}$ 8.8, in the presence of a protease inhibitor cocktail containing $1 \mathrm{mM}$ phenylmethanesulfonyl fluoride (PMSF), $20 \mu \mathrm{M}$ DPhe-Pro-Arg chloromethyl ketone, $3 \mathrm{mM}$ benzamidine and $1 \mathrm{mM}$ ethylenediaminetetraacetic acid (EDTA), and incubated for $60 \mathrm{~min}$ at room temperature. Samples $(10 \mu \mathrm{L})$ of each venom were desalted using ZipTip $_{\mathrm{C} 4}$ (Millipore) and eluted with $50 \%(\mathrm{v} / \mathrm{v})$ acetonitrile $(\mathrm{ACN})$ containing $0.1 \%$ $(\mathrm{v} / \mathrm{v})$ trifluoroacetic acid (TFA). Venoms with or without desalting were tested at various concentrations on the MALDI-TOF sample plate. The best resolution was obtained with $0.3 \mu \mathrm{g} / \mu \mathrm{L}$ and after elution from ZipTip C $_{4}$ (Millipore). After these steps all venoms were analyzed at the same concentration $(0.3 \mu \mathrm{g} / \mu \mathrm{L})$ and using the same pre-treatment.

\section{Size exclusion chromatography}

Crude venom of $B$. jararaca $(800 \mathrm{mg}$ ) was fractionated by size-exclusion chromatography (SEC) on a Sephacryl S-200 column $(2.6 \times 100 \mathrm{~cm})$ equilibrated and percolated with
$20 \mathrm{mM}$ Tris- $\mathrm{HCl}$ in $150 \mathrm{mM} \mathrm{NaCl}, \mathrm{pH}$ 8.8. Elution was monitored by absorbance at $280 \mathrm{~nm}$, and fractions corresponding to molecular mass $<10 \mathrm{kDa}$ were divided into two pools. Samples were further treated with ZipTip $_{C 4}$ as described above.

\section{MALDI-TOFMS analysis}

Peptide mass analyses were performed using a Voyager DE PRO (Applied Biosystems) MALDI-TOF mass spectrometer. Samples $(1 \mu \mathrm{L})$ eluted from $\mathrm{ZipTip}_{\mathrm{C} 4}$ (described above) were mixed with $1-3 \mu \mathrm{L}$ of the matrix $\alpha$-cyano- 4 -hydroxycinnamic acid (CHCA) or 3,5-dimethoxy-4-hydroxycinnamic acid (SA) $(10 \mathrm{mg} / \mathrm{mL}$ in $50 \% \mathrm{ACN} / 0.1 \% \mathrm{TFA})$, and then $1 \mu \mathrm{L}$ was spotted on the plate. Each sample was analyzed in positive linear and/or reflector ion modes, using external calibration with angiotensin I $(\mathrm{m} / \mathrm{z}$ 1,297.51), adrenocorticotropic hormone $(\mathrm{m} / \mathrm{z} 2094.46,2466.72$ and 3660.19), insulin $(\mathrm{m} / \mathrm{z}$ 5734.59), thioredoxin ( $m / z 11$ 674.48), and apomyoglobin $(\mathrm{m} / z 16$ 952.56). Known venom toxins were also used in some cases as standard references for internal multipoint calibration. Standard errors of $0.05 \%$ and $0.01 \%$ were permitted for MALDI-TOFMS mass measurements in the linear and reflective modes, respectively. Samples were analyzed in triplicate using 10 runs in each case with 50 laser shots across the MALDI spot. Parameters of the acquisition method were: accelerating grid and guide-wire potentials of 20000, 18800 and $10 \mathrm{~V}$, respectively; $400 \mathrm{~ns}$ delayed extraction setting. Spectra were obtained in the ranges $\mathrm{m} / \mathrm{z} 800-10000$ and 800-30000.

\section{De novo sequencing}

MS/MS analyses were performed using an ABI 4700 proteomics analyzer with TOF-TOF optics (Applied Biosystems). The data were obtained using peptide samples mixed with a saturated matrix solution of CHCA $(1: 1 \mathrm{v} / \mathrm{v})$, and spotted onto an ABI MALDI-TOF/TOF sample plate. The mass spectrometry (MS) and tandem mass spectrometry (MS/MS) experiments were performed in the reflector mode with external calibration, using the calibration mixture Sequazyme Standard kit (Applied Biosystems). Peptide de novo sequencing was performed by precursor ion fragmentation in the presence and absence of $\mathrm{N}_{2}$ as collision-induced dissociation (CID) gas; the collision cell pressure was kept at $2.8 \times 10^{-6}$ Torr. All MS/MS spectra were analyzed manually; the sequences were determined by precise mass differences between adjacent $b^{\prime}$ ions (confirmed by $y^{\prime}$ ions). All leucine and isoleucine $\mathrm{d}, \mathrm{v}$ and $\mathrm{w}$ ions could be observed and assigned in the BPP sequences.

\section{RESULTS}

In order to determine all possible components present in the range of 800-10000 Da, we have developed different strategies of analyses by MALDI-TOFMS and MS/MS. It has been shown that sample analysis using at least two different matrices enhances the possibility of ionization of distinct peptides, thus increasing the number of determined ions. ${ }^{32}$ Therefore, we analyzed crude venoms directly using CHCA and SA, which provided better identification of masses below and above $m / z$ 5000, respectively. All figures 
illustrate the optimum spectra obtained for each sample in a specified range, using the matrix indicated in the legend.

Representative mass spectra of the five Bothrops venoms are displayed in Fig. 1. Many similarities and some variations were observed in both qualitative and quantitative features. Among Bothrops venoms some peptides were speciesspecific, e.g., $m / z$ 1218, 1279 and 1392 for B. insularis; $m / z$ 1175 and 1189 for B. jararacussu; $m / z 1059$ and 1215 for B. jararaca; $m / z$ 1053, 1064, 1164, 1281, 1292 and 1296 for B. neuwiedi; and $m / z 1009$ and 1221 for B.alternatus. The ion at $\mathrm{m} / \mathrm{z} 1370$ was observed for four out of five Bothrops species (B. insularis, B. jararacussu, B. jararaca, and B. neuwiedi). Other ions were detected in two or three different species, i.e., $\mathrm{m} / \mathrm{z}$ 1095 for B. jararacussu and B. jararaca; $m / z 1196$ for B. insularis, B. jararacussu, and B. jararaca; and $m / z 1101$ and 1299 for $B$. jararaca and B. neuwiedi. The venom of B. alternatus revealed the most unique profile for this range, with a major ion at $\mathrm{m} / \mathrm{z}$ 1221 . This component was also present in B. jararaca but with very low intensity. In addition, the characteristic $m / z 1370$ ion was not observed for B. alternatus crude venom.

Interestingly, components in the $m / z 7500$ range were observed only in the venoms of three Bothrops species (Fig. 2). The spectrum of $B$. insularis revealed a major ion at $m / z 7741$, and at least three other minor components $(\mathrm{m} / \mathrm{z} 7355,7579$ and 7612). The B. jararaca crude venom showed a distinctive ion at $m / z 7732$ and two that were less intense $(m / z 7661$ and 7869). The ions at $m / z 7741$ and 7732 , found in both B. insularis and B. jararaca venoms, may correspond to similar molecules

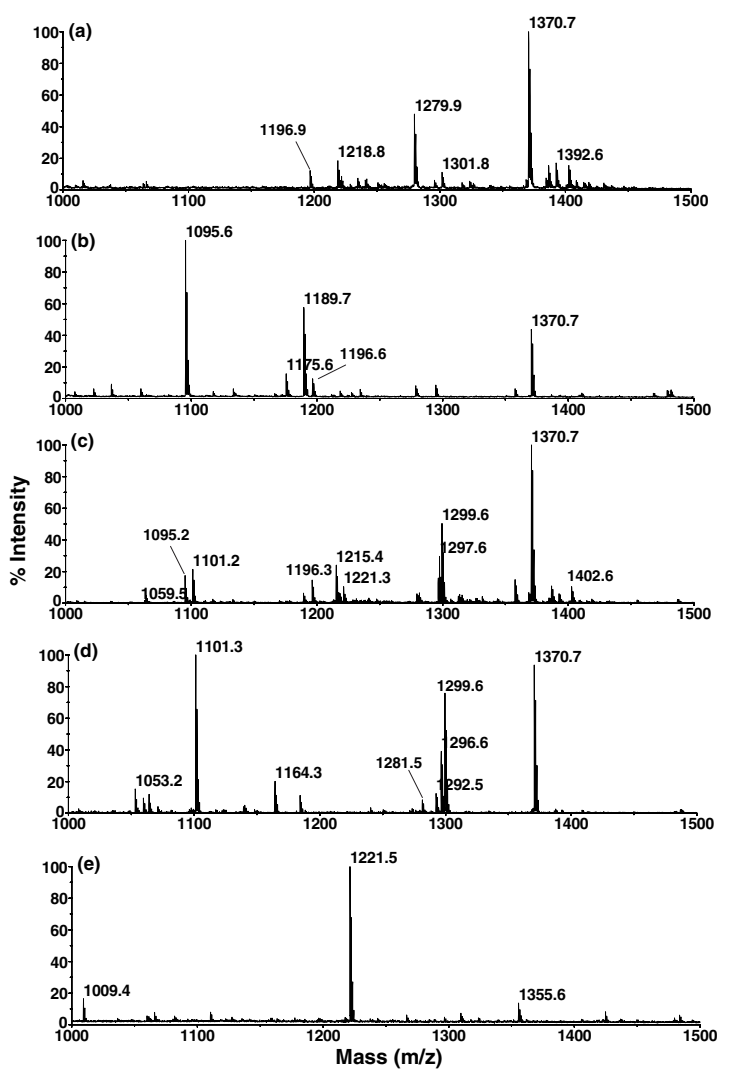

Figure 1. MALDI-TOFMS spectra of Bothrops sp. crude venoms using CHCA as matrix: (a) $B$. insularis; (b) $B$. jararacussu; (c) B. jararaca; (d) B. neuwiedi; and (e) B. alternatus.

Copyright (C) 2005 John Wiley \& Sons, Ltd.

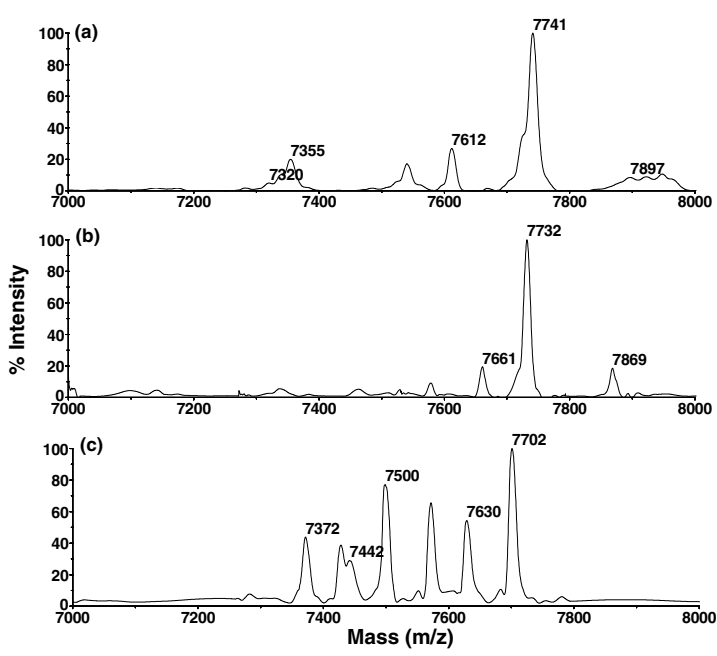

Figure 2. MALDI-TOFMS spectra of Bothrops sp. crude venoms using SA as matrix: (a) B. insularis; (b) B. jararaca; and (c) B. alternatus.

since their mass difference falls within the uncertainty range of $\pm 0.05 \%$ (Figs. 2(a) and 2(b)). Similarly to what was found in the lower mass range, $B$. alternatus venom once again yielded a rather distinct and more complex ion profile, containing at least seven different ions, i.e., $m / z$ 7372, 7430, $7442,7500,7572,7630$ and 7702.

Figure 3 shows the mass spectra of Crotalus sp. crude venoms, revealing quite different profiles for the three species analyzed. The ions at $\mathrm{m} / \mathrm{z} 4884$ and 4886 shown in Figs. 3(a) and 3(b), together with the corresponding doubly charged ions, were the only common components present in C. durissus terrificus and C. viridis venoms, respectively. C. durissus terrificus had two additional ions ( $m / z 1255$ and 4739) and Crotalus viridis exhibited a more complex profile with components in the regions of $\sim 1000 \mathrm{Da}(\mathrm{m} / \mathrm{z} 1064,1117$ and 1166) and $\sim 4500 \mathrm{Da}(\mathrm{m} / z$ 4234, 4858, 4961, 4985 and 5170).

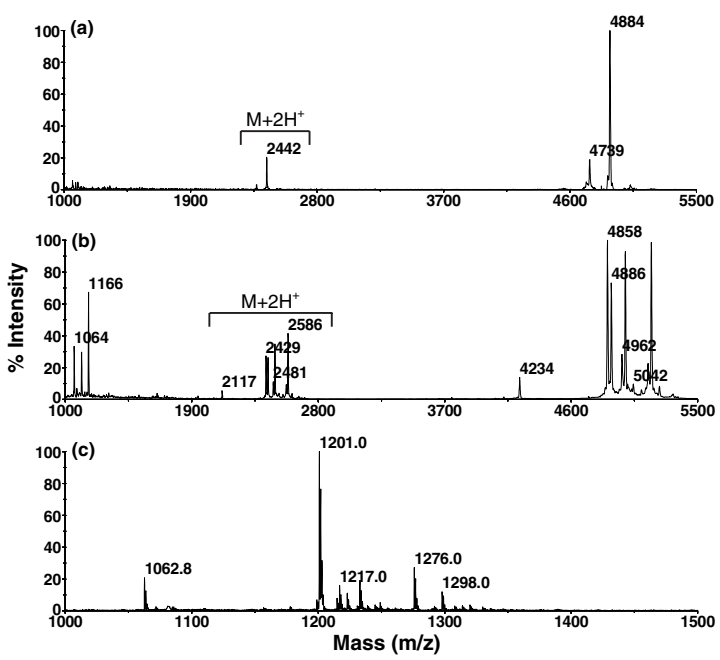

Figure 3. MALDI-TOFMS spectra of Crotalus sp. crude venoms using CHCA as matrix: (a) C. durissus terrificus; (b) C. viridis; and (c) C. adamanteus. $\mathrm{M}+2 \mathrm{H}^{+}$indicates doubly charged ions.

Rapid Commun. Mass Spectrom. 2005; 19: 1703-1708 


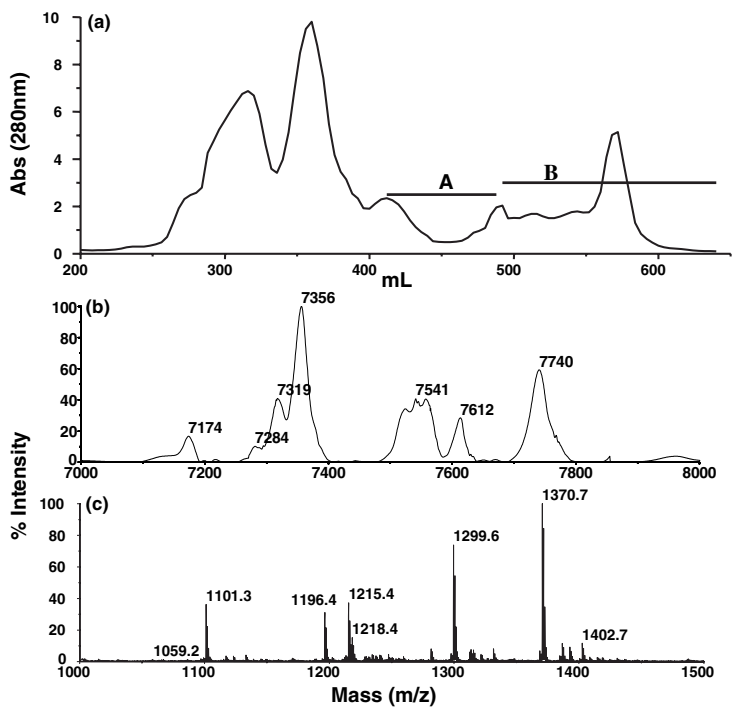

Figure 4. (a) Profile of $B$. jararaca crude venom separated by size exclusion chromatography on Sephacryl S-200. The protein elution was monitored at $280 \mathrm{~nm}$ and the fractions corresponding to molecular masses less than $10 \mathrm{kDa}$ were divided into two pools, A and B. A MALDITOFMS spectrum of each pool is shown. (b) lons detected in pool A ( $m / z 7000-8000)$ using SA as matrix and (c) ions detected in pool $B(m / z 1000-1500)$ using $C H C A$ as matrix.

Interestingly, the higher mass components were absent from C. adamanteus venom, which yielded ions only in the region of $\sim 1000 \mathrm{Da}(\mathrm{m} / \mathrm{z} 1062,1201,1217,1276$ and 1298).

In order to investigate possible differences between a prefractionated sample and the whole venom of $B$. jararaca, this venom was subjected to one step of purification (Fig. 4(a)). The crude venom was purified by SEC. Two pools, A and B, containing peptides with less than $10000 \mathrm{Da}$, were formed according to the elution profile. After this step, both pools were analyzed by MALDI-TOFMS using the same parameters adopted for the crude venom (Fig. 4). The spectrum of pool A was better resolved than that of the crude venom with regard to the main isoforms, and some other peptides appeared between $m / z 7000$ and 8000 (Fig. 4(b)). The analysis of pool B, however, showed the same peptide profile as the crude venom (Fig. 4(c)).

The peptides of $\sim 1000 \mathrm{Da}$ from the venoms of the Bothrops and Crotalus sp. were sequenced directly by MS/MS (Table 1). Figure 5 shows the interpretation of a representative MS/MS spectrum for the BPP peptide $(m / z$ 1196.76) found in $B$. insularis crude venom. The precursor ion was subjected to CID and the product ions were identified as internal fragments and/or b-series ions. The deduced amino-acid sequence and the identification of the pyroglutamic acid residue formed from glutamine are indicated across the top of the spectrum. All peptides shown in Table 1 were subjected to the same kind of analysis.

All sequenced peptides belong to the family of bradykininpotentiating peptides (BPPs). Several of these sequences are novel peptides, whereas others have already been described (Table 1). The peptides with $m / z 1059$ and 1255
Table 1. De novo sequencing of BPPs from snake venoms

\begin{tabular}{|c|c|c|c|}
\hline Snakes species & $\begin{array}{c}\text { Theoretical } \\
\text { mass } \\
{\left[\mathrm{M}+\mathrm{H}^{+}\right]}\end{array}$ & $\begin{array}{c}\text { Experimental } \\
\text { mass } \\
{\left[\mathrm{M}+\mathrm{H}^{+}\right]}\end{array}$ & Sequence obtained \\
\hline \multirow[t]{3}{*}{ B. insularis } & 1196.59 & 1196.41 & ZNWPHPQIPP 20 \\
\hline & 1279.72 & 1279.50 & ZLGPPPRPQIPP 20 \\
\hline & 1370.69 & 1370.81 & ZGGWPRPGPEIPP 20 \\
\hline \multirow[t]{4}{*}{ B. jararacussu } & 1095.60 & 1095.66 & ZGRPPGPPIPP* \\
\hline & 1189.65 & 1189.71 & ZARPPHPPIPP\# \\
\hline & 1196.59 & 1196.65 & ZNWPHPQIPP \# \\
\hline & 1370.69 & 1370.75 & ZGGWPRPGPEIPP \\
\hline \multirow{6}{*}{ B. jararaca } & 1059.53 & 1059.94 & ZGGAGWPPIPP* \\
\hline & 1101.30 & 1101.46 & ZWPRPQIPP $4,23,24$ \\
\hline & 1196.59 & 1196.65 & ZNWPHPQIPP ${ }^{4,21,23}$ \\
\hline & 1215.40 & 1215.49 & ZNWPRPQIPP ${ }^{4,24}$ \\
\hline & 1299.50 & 1299.75 & ZWPRPTPQIPP ${ }^{4,24}$ \\
\hline & 1370.69 & 1370.76 & ZGGWPRPGPEIPP ${ }^{4,21}$ \\
\hline \multirow[t]{3}{*}{ B. neuwiedi } & 1101.30 & 1101.72 & ZWPRPQIPP* \\
\hline & 1299.50 & 1299.85 & ZWPRPTPQIPP* \\
\hline & 1370.69 & 1370.85 & ZGGWPRPGPEIPP 22 \\
\hline B. alternatus & 1221.54 & 1221.46 & ZWPDPSSDIPP* \\
\hline C.d. terrificus & 1255.68 & 1255.36 & ZRWPHLEIPP ${ }^{\#}$ \\
\hline \multirow[t]{3}{*}{ C. viridis } & 1063.51 & 1063.63 & ZSAPGNEAIPP* \\
\hline & 1116.55 & 1116.65 & ZGGAPWNPIPP* \\
\hline & 1165.61 & 1165.72 & ZGPSPRHPIPP* \\
\hline \multirow[t]{2}{*}{ C. adamanteus } & 1201.61 & 1201.73 & ZGGWPRNPIPP* \\
\hline & 1276.62 & 1276.71 & ZQWPPGHHIPP* \\
\hline
\end{tabular}

*New BPP sequenced in this work.

\#BPPs deposited in NCBI bank (AAP 83422 and AAL 09426).

$\mathrm{Z}=$ pyroglutamic acid.

for B. jararaca and C. d. terrificus were readily visible in the MALDI-TOF spectrum in Figs. 1(c) and 3(a), respectively. On the other hand, these peptides can be detected and their sequences determined by MALDI-TOF/TOF (Table 1). Ten new BPP peptides were identified: $m / z \quad 1095$ for $B$. jararacussu; m/z 1059 for B. jararaca; $m / z 1101$ and 1299 for B. neuwiedi; $m / z 1221$ for B. alternatus; $m / z$ 1063, 1116 and 1165 for C. viridis; and $m / z 1201$ and 1276 for C. adamanteus. The cDNA sequence of the precursor of three peptides $(\mathrm{m} / \mathrm{z}$ 1189,1196 and 1370) from B. jararacussu sequenced in this work is deposited in the National Center Biotechnology Information (NCBI) bank (AAP 83422), as well as the cDNA sequence of a precursor for one peptide $(m / z$ 1255) from C. d. terrificus (AAL 09426).

\section{DISCUSSION}

The results presented in this work demonstrate that MALDITOFMS is a very fast and efficient method for preliminary studies of crude venom mixtures. Obviously, the utility of this methodology is not restricted to investigations of venomous snakes. It could easily be extended to other venomous animals or even to other tissues or biological extracts. ${ }^{14,33-36}$

We describe here a methodological approach for detecting and identifying a large number of peptides found in whole snake venoms. Novel BPP-related peptides were found in six out of eight crude venoms. Some of the identified peptides were previously reported either from cDNA data or as purified peptides. Some of the known toxins from these venoms could be identified by their molecular masses, such as BPPs. In all Bothrops and Crotalus species analyzed in this 


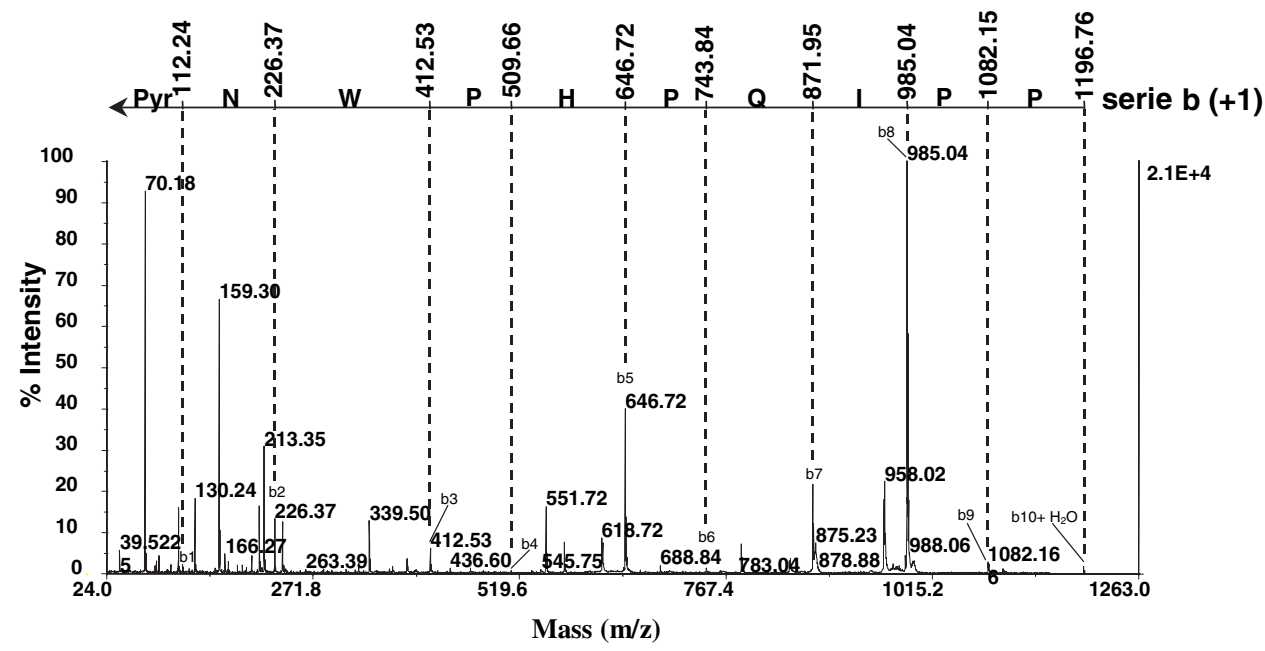

Figure 5. Representative MS/MS profile of a peptide found in the crude venom of $B$. insularis. The ion at $\mathrm{m} / \mathrm{z} 1196$ was selected for CID fragmentation for de novo sequencing. The deduced sequence is shown across the top of the MS/MS profile. This spectrum shows the b-ion series as well as some internal fragments.

work we have found at least one peptide that belongs to this family. These peptides were discovered and characterized previously in venoms from $B$. jararaca, $B$. insularis, $B$. neuwiedi, and B. jararacussu. ${ }^{3,15-22}$ A precursor of BPP (AAL 09426), originating from Crotalus d. terrificus venom gland cDNA, is deposited in the NCBI bank (unpublished) and contains the same peptide sequence shown here. Thus, by this simple analysis, we were able to confirm the presence of this putative molecule in crude venom.

In spite of the fact that many BPPs for these species have already been described, we demonstrate here the presence of many new versions. For instance, a powerful hypotensive effect has been described for C. viridis envenomation and we show here, for the first time to our knowledge, the presence of BPPs in C. viridis and also in C. adamanteus and B. alternatus venoms. ${ }^{23,24}$ All the BPPs shown in Table 1 possess a short motif IIe-Pro-Pro (IPP) at the C-terminus and a posttranslational modification at the $\mathrm{N}$-terminus that transforms glutamine into pyroglutamic acid. These peptides are rich in proline residues, containing from three to six Pro residues. The molecular and pharmacological features of the BPPs make them leading candidates for the development of novel molecules for use in the treatment of high blood pressure. ${ }^{23,25}$ The pharmacological activities of these newly identified peptides have yet to be described. Nevertheless, the description of new compounds is important since comparisons among the activities of these peptides can contribute to the rational design of new drugs.

The results presented in Fig. 2 indicate that B. insularis and $B$. jararaca possess the same profile in the $m / z 7000-8000$ range, confirming that these two species are closely related. As expected, their more distant relative B. alternatus showed a very different profile (Fig. 2(c)). The occurrence of multiple isoforms has already been described for the venom components of many snake species, that probably occur for the peptides in the range $m / z 7000-8000 .{ }^{12,26,27}$

After the pre-fractionation of $B$. jararaca venom, the spectrum of pool A (Fig. 4(a)) exhibited an improvement in resolution when compared with that of crude venom in the same range. On the other hand, pool B (Fig. 4(b)) from B. jararaca exhibited the same profile as that of the crude venom in the MALDI-TOF analysis. These results suggest that, at least for samples with mass below $2000 \mathrm{Da}$, a pre-fractionation step is not necessary, and that, for masses above $7000 \mathrm{Da}$, this step provides a better resolution of many isoforms.

Crotalus $d$. terrificus venom exhibited two components around $\mathrm{m} / \mathrm{z} 4800$ (Fig. 3(a)), previously characterized as isoforms of crotamine. ${ }^{28-30}$ Crotalus viridis has a number of isoforms of this myotoxin (Fig. 3(b)), including peptides of $m / z 4886,4985$ and 5171. Myotoxin isoforms of this size have already been described for C.d. terrificus, C. v. helleri and C. v. viridis. ${ }^{10,30,31}$ Other ions observed in this same region have not yet been described and may correspond to isoforms of novel myotoxins.

Some of the observed ions could not be assigned to known compounds. This illustrates the fact that snake venoms are complex and contain many compounds that have not yet been described. The use of MS/MS to analyze crude extracts should facilitate the classification and understanding of the biological activity of unknown compounds, and may be of help in the search for new families of bioactive compounds with or without toxic activities. Mass spectrometry will certainly play an essential role in such investigations, as it is not restricted to molecular mass assessment, but can also detect post-translational modifications.

Finally, the technique of toxin mass fingerprinting can also be extremely useful for quality control of crude venom batches, which is essential in venom and antivenom production and for eliciting structural information on individual toxins.

\section{Acknowledgements}

We are grateful to Instituto Butantan for generously providing Bothrops insularis and Bothrops jararaca crude venoms. We would like to thank Dr Martha Sorenson and Dr Robson Q. 
Monteiro for careful revision of the manuscript, and Ms Dione Maria da Silva for technical assistance. This work was supported by Conselho Nacional de Desenvolvimento Científico (CNPq), Fundação de Amparo à Pesquisa do Estado do Rio de Janeiro (FAPERJ), Coordenação de Aperfeiçoamento de Pessoal de Nível Superior (CAPES), Laboratório Nacional de Luz Síncrotron (LNLS) and Fundação de Amparo à Pesquisa do Estado de São Paulo (FAPESP) (Brazil).

\section{REFERENCES}

1. Francischetti IMB, Castro HC, Zingali RB, Célia RC, Guimarães JA. Comp. Biochem. Physiol. C Pharmacol. Toxicol. Endocrinol. 1998; 119: 21.

2. Stöckin R, Mebs D, Boulain J-C, Panchaud PA, Virelizier H, Gillard-Factor C. Methods Mol. Biol. 2000; 146: 317.

3. Ianzer D, Konno K, Marques-Porto $\mathrm{R}$, Portaro FCV, Stöcklin R, Camargo ACM, Pimenta DC. Peptides 2004; 25: 1085.

4. Coelho ALJ, Freitas MS, Oliveira-Carvalho AL, Moura-Neto V, Zingali RB, Barja-Fidalgo C. Exp. Cell. Res. 1999; 251: 379.

5. Scarborough RM, Rose JW, Naughton MA, Phillips DR, Nannizzi L, Arfsten A, Campbell AM, Charo IF. J. Biol. Chem. 1993; 268: 1058

6. Cominetti MR, Tenuggi CHB, Ramos OHP, Fox JW, MarianoOliveira A, De Freitas MS, Figueiredo CC, Morandi V, Selistre-de-Araujo HS. J. Biol. Chem. 2004; 279: 18247.

7. Nicastro G, Franzoni L, Chiara C, Mancin AC, Giglio JR, Spisni A. Eur. J. Biochem. 2003; 270: 1969.

8. Rádis-Baptista G, Oguiura N, Hayashi MAF, Camargo ME, Grego KF, Oliveira EB, Yamane T. Toxicon 1999; 37: 973.

9. Nawarak J, Sinchaikul S, Wu CY, Ming-Yi L, Phutrakul S, Shui-Tein C. Electrophoresis 2003; 24: 2838.

10. Griffin PR, Aird SD. FEBS Lett. 1990; 274: 43.

11. Jürgens M, Schrader M. Curr. Opin. Mol. Ther. 2002; 4: 236.

12. Creer S, Malhotra A, Thrope RS, Stöcklin R, Favreau P, Chou WH. J. Mol. Evol. 2003; 56: 317.

13. Papayannopoulos IA. Mass Spectrom. Rev. 1995; 14: 49.

14. Svensson M, Sköld K, Svenningsson P, Andren PE. J. Proteome Res. 2003; 2: 213.
15. Junqueira-de-Azevedo I de L, Ho PL. Gene 2002; 299: 279.

16. Hayashi MAF, Murbach AF, Ianzer D, Portaro FC, Prezoto BC, Fernandes BL, Silveira PF, Silva CA, Pires RS, Britto LR, Dive V, Camargo AC. J. Neurochem. 2003; 85: 969.

17. Ferreira LAF, Galle A, Raida M, Schrader M, Lebrun I, Habermehl G. J. Protein Chem. 1998; 17: 285.

18. Ferreira SH, Bartelt DC, Greene LJ. Biochemistry 1970; 9: 2583.

19. Ondetti MA, Williams NJ, Sabo EF, Pluscec J, Weaver ER, Kocy O. Biochemistry 1971; 10: 4033.

20. Murayama N, Hayashi MA, Ohi H, Ferreira LA, Hermann VV, Saito H, Fujita Y, Higuchi S, Fernandes BL, Yamane T, de Camargo AC. Proc. Natl. Acad. Sci. USA 1997; 94: 1189.

21. Cintra AC, Vieira CA, Giglio JR. J. Protein Chem. 1990; 9: 221.

22. Ferreira LA, Henriques OB, Lebrum I, Batista MBC, Prezoto BC, Andreoni ASS, Zelnik R, Habermehl G. Toxicon 1992; 30: 33 .

23. Hawgood BJ. Toxicon 1997; 35: 1569.

24. Schaeffer RC Jr, Pattabhiraman TR, Carlson RW, Russell FE, Weil MH. Toxicon 1979; 17: 447.

25. Cushman DW, Cheung HS, Sabo EF, Ondetti MA. Biochemistry 1997; 16: 5484.

26. Trikha M, Schmitmeier S, Markland FS. Toxicon 1994; 32 1521

27. Monteiro RQ, Carlini CR, Guimaraes JA, Bon C, Zingali RB. Toxicon 1997; 35: 649.

28. Toyama MH, Carneiro EM, Marangoni S, Barbosa RL, Corso G, Boschero AC. Biochim. Biophys. Acta 2000; 1474: 56.

29. Toyama MH, Marangoni S, Novello JC, Leite GB, Prado-Franceschi J, Cruz-Höfling MA, Rodrigues-Simioni L. Toxicon 2003; 41: 493.

30. Laure CJ. Hoppe Seylers Z. Physiol. Chem. 1975; 356: 213.

31. Maedan N, Tamiya N. Toxicon 1978; 16: 431.

32. Gonnet F, Lemaître G, Waksman G, Tortajada J. Protemome Sci. 2003; 1: 2

33. Pimenta AMC, Almeida FM, Lima ME, Martin-Eauclaire MF, Bougis PE. Rapid Commun. Mass Spectrom. 2003; 17: 413.

34. Pimenta AMC, Stöcklin R, Favreau P, Bougis PE, MarieEauclaire M-F. Rapid Commun. Mass Spectrom. 2001; 15: 1562.

35. Schulz-Knappe P, Zucht HD, Heine G, Jürgens M, Hess R, Schrader M. Comb. Chem. High-Throughput Screen. 2001; 4: 207.

36. Schrader M, Schulz-Knappe P. Trends Biotechnol. 2001; 19: S55. 